\title{
Cross-reactive rubella virus and glutamic acid decarboxylase (65 and 67) protein determinants recognised by T cells of patients with Type I diabetes mellitus
}

\author{
D. Ou ${ }^{1}$, L.A.Mitchell ${ }^{2}$, D. L. Metzger ${ }^{1}$, S. Gillam ${ }^{2}$, A.J. Tingle ${ }^{1}$ \\ ${ }^{1}$ Departments of Paediatrics, Faculty of Medicine, The University of British Columbia, Vancouver, British Columbia, Canada \\ ${ }^{2}$ Department of Pathology, Faculty of Medicine, The University of British Columbia, Vancouver, British Columbia, Canada
}

\section{Abstract}

Aims/hypothesis. To examine the cross-reaction between viral and beta-cell protein determinants and to further understand the potential role of this mechanism in Type I (insulind-dependent) diabetes mellitus. Methods. Immune responses to a panel of 28 viral and beta-cell protein peptides representing selected sequences of rubella virus (RV), Coxsackie virus, human $38 \mathrm{KDa} 31 \mathrm{G}$ and glutamic acid decarboxylase (GAD 65 and 67) proteins in proliferation or cytotoxicity assays have been studied using uncloned and cloned T-cell cohorts from a group of 60 Type I diabetic patients.

Results. Peptide GAD65(252-266) induced the responses of patients with recent onset diabetes in proliferation assays at the highest frequency (77\%), whereas GAD67(212-226) stimulated the cellular responses at the highest rate $(61 \%)$ in patients with late-onset diabetes. RVE1(157-176) was recognised by all groups of patients at the highest frequency and the largest amplitude among the viral peptides tested. T-cell clones specific to GAD65(252-266), GAD65(274-286) or GAD67(212-226) were tested in cytotoxicity assays for their responses to rubella virus peptides. Each of these T-cell clones cross-reacted with two to four rubella virus peptides, including RVE1(157-176) and RVE2(87-107). Analysis of the sequences of cross-reactive viral and glutamic acid decarboxylase antigens showed that these epitopes shared similar peptide binding motifs to HLA DR3/ DR4. There is a statistically significant correlation between the response amplitude of patient's peripheral blood mononuclear cells to RVE1(157-176), RVE2(87-107) and GAD65(274-286) in patients with recent onset diabetes, and to RVE1(157-176) and GAD67(212-226) in patients with late onset diabetes.

Conclusion/interpretation. Cross-reactive glutamic acid decarboxylase and rubella virus determinants identified by T-cell clones were also recognised at high frequencies by general T-cell populations of Type I diabetic patients. [Diabetologia (2000) 43: 750-762]

Keywords Autoreactivity, autoimmune disease, Coxsackie, glutamic acid decarboxylase, Type I diabetes, rubella, T-cell epitope.
Received: 4 October 1999 and in final revised form: 24 January 2000

Corresponding author: Dr. D. Ou, Dept. of Pediatrics, Faculty of Medicine, The University of British Columbia, 950 West 28th Ave., Vancouver, B. C. Canada V5Z 4H4

Abbreviations: BLS, Bare lymphocyte syndrome; CMV, cytomegalovirus; CRS, congenital rubella syndrome; CTL, cytotoxic T lymphocyte; CXV, Coxsackie virus; GAD, glutamic acid decarboxylase; LCMV, lymphocytic choriomeningitis virus; MHC, major histocompatibility complex; NOD, non-obese diabetic; PBMC, peripheral blood mononuclear cells; RIP, rat insulin promoter; RV, rubella virus; SI, stimulation index; TCR, T-cell receptor; V, virus; PAH, phytohaemaglutinin.
Type I (insulin-dependent diabetes) mellitus, is caused by the progressive loss of insulin-producing pancreatic beta cells and is generally believed to result from T-cell-mediated autoimmune destruction $[1,2]$. Type I diabetes has long been known as a hereditary disease whose aetiology seems to be polygenic and multifactorial. The role of HLA genes in susceptibility to Type I diabetes is important, as indicated by high disease concordance in $H L A$-identical siblings (15-17\% in DR3/4 heterozygotes, compared with approximately $1 \%$ for $H L A$-discordant siblings). Although a genetic predisposition to Type I di- 
abetes in humans has been clearly established, the observed $60 \%$ discordance rate for Type I diabetes between identical twins suggests that environmental factors such as viruses and diet could be important aetiological determinants [1-3]. The viruses that have been most frequently implicated in the pathogenesis of human Type I diabetes are the rubella virus (RV), cytomegalovirus (CMV), mumps virus and the Coxsackie virus (CXV) [1,4]. The best-documented information linking a preceding viral infection in humans with the subsequent onset of diabetes has come from studies of children and young adults who were infected with RV during intra-uterine development and subsequently diagnosed as having congenital rubella syndrome (CRS) $[1,4,5]$. The incidence of insulin-dependent diabetes in CRS patients has been estimated to be $10-12 \%$ whereas up to $40 \%$ of CRS patients show impaired glucose tolerance $[3,6$, 7]. Results of studies in mice and humans with Type I diabetes suggest that beta-cell destruction could occur directly as a result of viral replication or indirectly due to viral bystander damage or viral induction of autoimmune cell damage $[1,4,8]$. Virus infection could break the tolerance of T-cells to beta-cell antigens by damaging beta cells, and thus releasing a high load of autoantigens or by cross-reaction between viral and beta-cell epitopes [1, 4]. The latter mechanism involves molecular (antigenic) mimicry in which infection with a virus results in activation of lymphocytes that not only recognise a particular determinant of the invading virus, but also a molecularly similar determinant from a selfprotein. Thus, a transgenic mouse model has served as a tool to understand the pathogenetic processes involved in the initial phase of autoimmune reaction [9]. The advantage is that a well-characterised foreign (e.g. viral) gene can be expressed as a self-antigen and autoreactive immune responses followed precisely. In this way, it was shown that lymphocytic choriomeningitis virus (LCMV) infection caused Type I diabetes in over $90 \%$ of rat insulin promoter (RIP)-LCMV transgenic mice. This not only established a direct link between viral infection and onset of Type I diabetes but also pointed to self-protein immunisation as a probable pathogenetic mechanism in this model [9].

In the last few years, considerable progress has been made in the identification of candidate Type I diabetes autoantigens recognised by autoantibodies [10-13]. Several of these candidate autoantigens are recognised by T-cells, including insulin, GAD, heatshock protein 65, IA-2, and ICA69 [11, 13]. Glutamic acid decarboxylase, a putative beta-cell autoantigen, exists in the two isoforms 65000 and $67000 \mathrm{M}_{\mathrm{r}}$, previously detected by immunoprecipitation of islet extracts using sera from diabetic patients [14]. Both GAD65 and 67 are expressed in the islets of Langerhans and in the brain in humans $[14,15]$ and appear to be the primary autoantigens in Type I diabetics
[15-21]. Anti-GAD antibodies have been found in $60-70 \%$ of diabetic and in most prediabetic subjects $[16,17]$. T-cells from Type I diabetic patients were induced to proliferate in vitro by GAD65 and GAD67 proteins and their peptides $[17,18]$.

Observed amino acid sequence similarity (homology) between antigens of CXV, or CMV and betacell antigens and cross-reaction by T-cells or antibodies or both with these antigens from Type I diabetic patients support the molecular mimicry mechanism of pathogenesis [3, 4, 15, 22-23]. Peripheral blood mononuclear cells (PBMC) from patients with or at increased risk for Type I diabetes showed increased reactivity to specific regions, respectively, GAD65 (amino acids 247-279) and the CXV B4 P2-C protein (amino acids 32-47) [24]. Cross-reactivity between a domain within RV capsid protein amino acids 65000-79000 and a 52000 $\mathrm{M}_{\mathrm{r}}$ protein expressed on human and rat pancreatic islet cells has been defined with a monoclonal antibody [25]. Although there might not be a single infectious trigger for Type I diabetes, multiple infectious agents such as CXV, RV and CMV could have common antigenic motifs capable of activating autoreactive antibodies and T-cells [3, 26]. Persistent rubella viral infection has been observed in pancreases of some infants born with CRS [27]. Rubella virus can infect cultured human fetal pancreatic islet cells and such infection could lead to significant reductions in concentrations of secreted insulin [28]. Patients with Type I diabetes associated with CRS show the same immunogenetic (DR3 or DR4 or both) associations as conventional Type I diabetic patients [29]. Thus, CRS-associated Type I diabetes serves as an excellent human model in which to study viral influences in the pathogenesis of diabetes [7]. There are, however, no reports of cross-reactions between T-cell epitopes of rubella virus and beta-cell proteins so far. Two pairs of overlapping nonamer T-cell epitopes within GAD65 protein recognised by both $\mathrm{CD}^{+}$or $\mathrm{CD} 8^{+} \mathrm{T}$-cells were identified as sequences bounded by GAD65(255-266) with 6/9 overlapping residues, and GAD65(276-285) with 8/9 overlapping residues, respectively using $\mathrm{CD} 4^{+}$and $\mathrm{CD} 8^{+}$T-cell clones from patients with CRS-associated Type I diabetes in one of our studies [30]. In the study reported here, we further investigated relations between RV infection and Type I diabetes by examining T-cell responses of patients with Type I diabetes to RV and beta-cell antigens. Several cross-reactive $\mathrm{RV}$ and GAD protein determinants were identified and evaluated.

\section{Subjects and methods}

Subjects. Patients with Type I diabetes were selected for this study based on the inclusion criteria of established diagnosis of Type I diabetes, clinically stable, and attending ambulatory 
Table 1. Cellular responses of Type I diabetic and CRS patients to beta-cell protein peptides

\begin{tabular}{|c|c|c|c|c|c|}
\hline & \multirow{3}{*}{$\begin{array}{l}\text { Beta-cell peptides }^{\mathrm{a}} \\
\text { (position) }\left(\text { reference) }^{\mathrm{c}}\right.\end{array}$} & \multicolumn{2}{|c|}{ Patients with Type I diabetes } & \multicolumn{2}{|l|}{ CRS patients } \\
\hline & & Recent onset ${ }^{\mathrm{b}}$ & Late onset & with Type I diabetes & without Type I diabetes \\
\hline & & \multicolumn{2}{|c|}{${\text { (positive ratio })^{\mathrm{d}}}$} & \multicolumn{2}{|l|}{ (positive ratio) } \\
\hline B2 & GAD65 (252-266) (20) & $20 / 26$ & 17/31 & $2 / 3$ & $5 / 8$ \\
\hline B3 & GAD65 (256-279) (20) & $11 / 26$ & $4 / 31$ & $0 / 3$ & $0 / 8$ \\
\hline B4 & GAD65 (274-286) (39) & $10 / 26$ & $10 / 31$ & $2 / 3$ & $1 / 8$ \\
\hline B7 & GAD65 (521-535) (37) & $7 / 26$ & $7 / 31$ & $1 / 3$ & $1 / 8$ \\
\hline B8 & GAD67 (152-166) $(15,16)$ & $6 / 26$ & $3 / 31$ & $0 / 3$ & $1 / 8$ \\
\hline B9 & GAD67 (166-180) $(15,16)$ & $12 / 26$ & $15 / 31$ & $1 / 3$ & $3 / 8$ \\
\hline B10 & GAD67 (212-226) $(15,16)$ & $13 / 26$ & $19 / 31$ & $3 / 3$ & $1 / 8$ \\
\hline B11 & GAD67 (221-235) $(15,16)$ & $11 / 26$ & $11 / 31$ & $1 / 3$ & $2 / 8$ \\
\hline
\end{tabular}

${ }^{\text {a }} \mathrm{GAD}$, glutamic acid decarboxylase; $\mathrm{B}$, beta.

${ }^{\mathrm{b}}$ Recent onset, less than 6 months after initial Type I diabetes diagnosis; late onset, more than 6 months after diagnosis.

${ }^{c}$ Position, location of the peptide within beta-cell protein; Reference, number of the reference paper in which the beta-cell antigen containing the peptide sequence was identified.
${ }^{\mathrm{d}}$ Number of patients with positive T-cell response $(\mathrm{SI} \geq 2.0)$ to the peptide in PBMC proliferation assays/number of patients in the group.

e Beta-cell antigens in boldface indicate the specific peptides recognised by $\mathrm{T}$-cell clones used in this study
Diabetic Clinic of British Columbia's Children's Hospital. Exclusion criteria included clinical instability, and immunosuppressive therapy. Study subjects included 26 patients with recent onset Type I diabetes and 31 with late onset (more than 6 months after diagnosis) Type I diabetes, three patients with CRS-associated Type I diabetes and eight CRS patients without Type I diabetes. Two patients with CRS-associated Type I diabetes, SZ and DB were the donors of the T-cell clones used in this study. The study protocols were approved by the research ethics committees of the University of British Columbia and British Columbia's Children's Hospital. Patient (and/ or parent or guardian) informed consent or both was obtained in all cases.

Antigens. A panel of peptides of human beta-cell proteins of GAD65, GAD67 and $38 \mathrm{KDa} 31 \mathrm{G}$ (positions shown in Table 1) and a panel of peptides of viral proteins [rubella virus $\mathrm{E} 1, \mathrm{E} 2$ and $\mathrm{C}$ and Coxsackie $\mathrm{B} 4$ virus $\mathrm{P} 2-\mathrm{C}$ (positions shown in Table 2 and Table 3)] were synthesised in an automated ABI 430 A peptide synthesiser (Syndrgy, Foster City, Calif., USA) using standard solid-phase methods [31]. The identity and the purity of the peptides had been analysed by mass spectrometry. For each peptide, amino acid analyses were carried out and found to be in agreement with the theoretical composition. Whole virus of RV strain M33 heat-inactivated by incubation at $56^{\circ} \mathrm{C}$ for $30 \mathrm{~min}$ was also used as a stimulating antigen in proliferation assays.

Proliferation assay. For the proliferation assays using peripheral blood mononuclear cells (PBMC) as responder cells, $1 \times 10^{5}$ cells per well were incubated with peptide at a concentration of $10 \mu \mathrm{mol} / \mathrm{l}$, or with heat-inactivated whole RV virus at $1 \times 10^{6}$ $\mathrm{pfu} / \mathrm{ml}$ or with phytohaemagglutinin (PHA) at a final concentration of $10 \mu \mathrm{g} / \mathrm{ml}$ as stimulation (positive) controls in complete Opti-MEM I medium (Gibco BRL, Missisauga, Ont., Canada) containing $2 \mathrm{mmol} / \mathrm{l} \mathrm{L}$-glutamine, $1 \mathrm{mmol} / \mathrm{l}$ sodium pyruvate, $25 \mathrm{mmol} / 1 \mathrm{HEPES}, 50 \mathrm{mmol} / 1$ penicillin, $50 \mathrm{mmol} / \mathrm{l}$ streptomycin and $5 \times 10^{-5} \mathrm{~mol} / 1$ 2-mercaptoethanol supplemented with $10 \%$ autologous plasma for 7 days as described previously [31, 32]. Negative control (background) wells received only complete medium supplemented with autologous plasma. For the assays using cloned T-cells as responder cells, a total of $1 \times 10^{4}$ cells per well were incubated with autologous, gamma-irradiated $(2500 \mathrm{rad}) \mathrm{PBMC}\left(5 \times 10^{4}\right.$ cells per well $)$ in complete RPMI 1640 medium containing $2 \mathrm{mmol} / \mathrm{l} \mathrm{L-gluta-}$ mine, $25 \mathrm{mmol} / \mathrm{l} \mathrm{HEPES}, 50 \mathrm{mmol} / \mathrm{l}$ penicillin, $50 \mathrm{mmol} / \mathrm{l}$ streptomycin, and $5 \times 10^{-5} \mathrm{~mol} / \mathrm{l}$ 2-mercaptoethanol, $10 \%$ FCS and peptide at a concentration of $10 \mu \mathrm{mol} / 1$ in $96-w e l l$ flat-bottom plates for 3 days as described previously [31, 32]. The proliferation assays with the beta-cell peptides, viral antigens and PHA as stimulators including negative controls were carried out on the same assay plate for comparison. The cell cultures were pulsed with $37 \mathrm{kBq}$ of (methyl- ${ }^{3} \mathrm{H}$ ) thymidine (Amersham, Oakville, Ont., Canada) per well for the last $6 \mathrm{~h}$ and incorporated radioactivity was determined. Results are presented as the stimulation index, which is the ratio of the mean cpm incorporated in the presence of antigen to the mean cpm obtained in the absence of antigen. The mean cpm were obtained from triplicate determinations. A stimulation index (SI) value greater than or equal to 2 was considered indicative of a positive response to the viral and beta-cell antigens and PHA.

All positive results were verified by carrying out a twotailed $t$ test of the mean gross counts per min obtained with stimulated and unstimulated (negative control) wells. Significance of the mean responses in a group of patients of an individual peptide, compared with those of other peptides was examined by post hoc tests using analysis of variance (ANOVA). Correlation between the responses in a group of patients to two individual peptides was tested by Pearson's correlation analysis. Significance of the positive response frequency to an individual peptide, compared with those of other peptides was examined by the chi-squared test.

GAD protein (65 and 67) peptide-specific T-cell clones. T-cell clones used for this study were derived from two patients with CRS-associated Type I diabetes using methods previously described $[30,33]$. Briefly, PBMC were incubated with peptides, GAD65(252-266), GAD65(274-286), or GAD67(212-226) at a final concentration of $10 \mu \mathrm{mol} / \mathrm{l}$ in a complete RPMI 1640 medium supplemented with $10 \%$ autologous plasma. Starting on the fifth day of incubation at $37^{\circ} \mathrm{C}, 5 \mathrm{U} / \mathrm{ml}$ of human recombinant (r)IL2 (GIBCO, Missisauga, Ont., Canada) was added to the culture every 2 days. After 14 days, peptide- 
Table 2. T-cell responses of Type I diabetic and CRS patients to viral protein peptides of rubella and Coxsackie B4 viruses

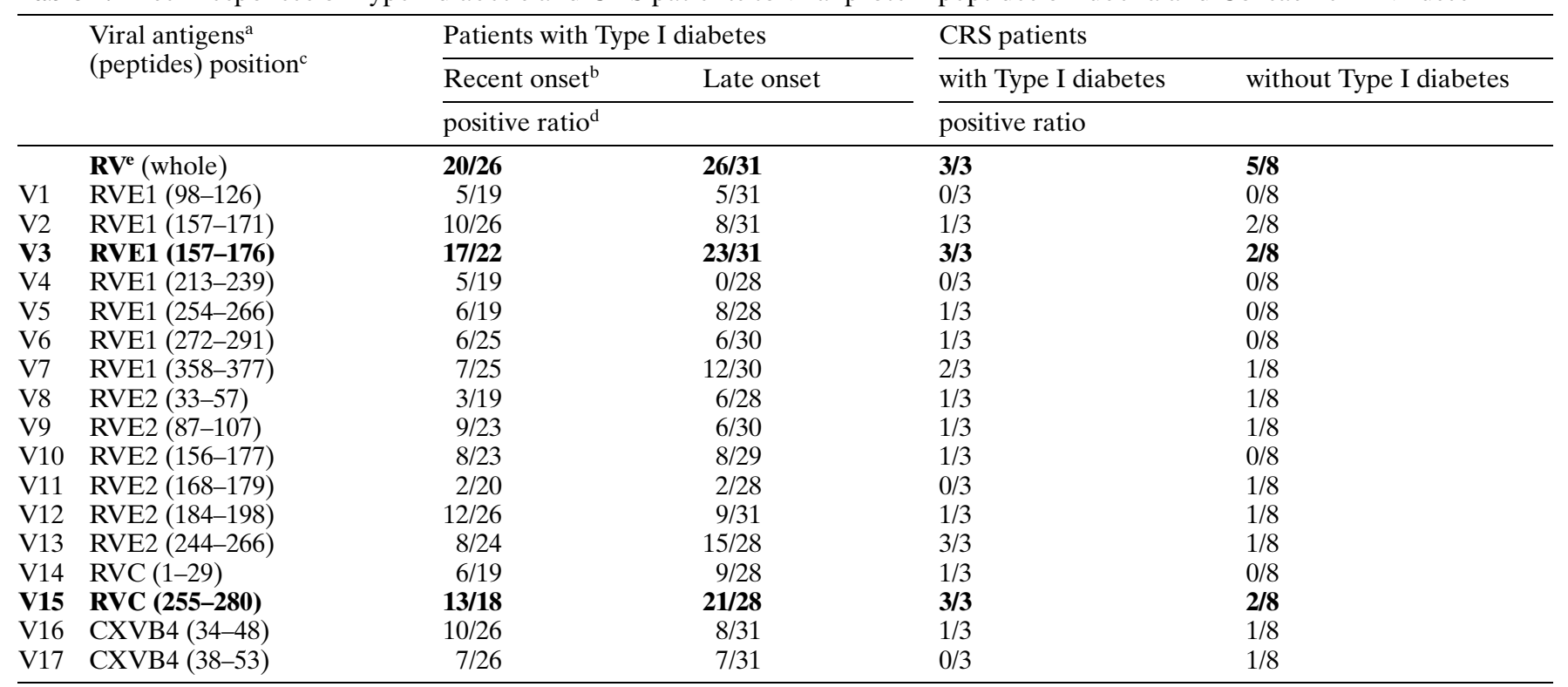

${ }^{\mathrm{a}} \mathrm{RV}$, rubella virus; CXVB4, coxsackie virus B4 P2-C protein; RV (whole), heat-inactivated RV strain M33 whole antigen $\left(10^{6} \mathrm{pfu} / \mathrm{ml}\right)$ which was inactivated at $56^{\circ} \mathrm{C}$ for $30 \mathrm{~min}$.

${ }^{\mathrm{b}}$ Recent onset, less than 6 months after diagnosis; late onset, more than 6 months after diagnosis.

${ }^{c}$ Position, location of the peptide within virus protein sequence.

Table 3. Specific cytotoxicity of GAD65(252-266)-specific T-cell clone SZ2.6 and GAD65(274-286)-specific T-cell clone DB4.7 to the specific GAD peptides and RV peptides presented by BLS-1.DRB1*0404 cell line

\begin{tabular}{lcc}
\hline Sensitising peptide & \multicolumn{2}{c}{ \% Specific cytotoxicity } \\
\cline { 2 - 3 } & clone SZ2.6 & clone DB4.7 \\
& $(\mathrm{E}: \mathrm{T}=10: 1)$ & $(\mathrm{E}: \mathrm{T}=5: 1)$ \\
\hline GAD65 (252-266) (B2) & $\mathbf{6 0 . 9}$ & - \\
GAD65 (274-286) (B4) & - & $\mathbf{2 7 . 3}^{\mathrm{b}}$ \\
RVE1 (18-38) & 2.1 & 0 \\
RVE1 (38-57) & 0 & 0 \\
RVE1 (54-74) & 2.1 & 0 \\
RVE1 (122-141) & $\mathbf{1 2 . 5}$ & 0 \\
RVE1 (157-176) & $\mathbf{2 7 . 4}$ & $\mathbf{2 6 . 2}$ \\
RVE1 (174-193) & 3.5 & 0 \\
RVE1 (190-209) & 0 & 0 \\
RVE1 (256-275) & 0 & 0 \\
RVE1 (258-377) & NT & 0 \\
RVE2 (33-57) & 0 & 5.3 \\
RVE2 (87-107) & 0.6 & $\mathbf{1 7 . 9}$ \\
RVE2 (156-177) & NT & 0 \\
RVE2 (233-257) & 0 & 0 \\
RVC (1-29) & 0 & 0 \\
RVC (53-78) & 0 & 2.4 \\
RVC (151-179) & 0 & 0 \\
RVC (177-204) & NT & 0 \\
RVC (231-257) & NT & 0 \\
NONE & 0 & 0 \\
\hline
\end{tabular}

${ }^{\text {a }} \mathrm{E}$ :T, effector T-cells : peptide sensitised BLS-1 target cells ratio in cytotoxicity assays.

${ }^{\mathrm{b}}$ NT, not test; numbers in boldface indicate \% specific cytotoxicity greater than 10
${ }^{\mathrm{d}}$ Number of patients with positive T-cell response $(\mathrm{SI} \geq 2.0)$ to the peptide in peripheral blood mononuclear proliferation assays/number of patients in the group.

e Antigens in boldface indicate their positive response frequencies more than $70 \%$ in patients with Type I diabetes

reactive lymphocytes were cloned by limiting dilution in 96well round-bottom plates (Nunc, Napierville, Ill., USA) at an initial density of 0.3 cells per well in a complete medium supplemented with $10 \%$ human AB serum (Sigma, St. Louis, Mo., USA), $10 \mathrm{U} / \mathrm{ml}$ of rIL2, $10 \mu \mathrm{mol} / 1$ peptide, $5 \%$ Lymphocult-T-LF (Biotest, Dreieich, Germany), and gamma-irradiated $(2500 \mathrm{rad})$ autologous PBMC $\left(5 \times 10^{4}\right.$ per well $)$. After 7 days, all wells were supplemented with complete RPMI 1640 medium containing 5\% Lymphocult-T-LF and $20 \mathrm{U} / \mathrm{ml}$ rIL2. The clones were tested for specificity in proliferation assays using the peptides, GAD65(252-266), GAD65(274-286) or GAD67(212-226).

HLA DR cDNA-transfected bare lymphocyte syndrome (BLS)-1 cell line. BLS-1 transfectant cells were used as peptide-sensitised targets in ${ }^{51} \mathrm{Cr}$ release cytotoxicity assays as previously described $[34,35]$ and detailed below. The BLS-1 cell line, an Ebstein-Barr virus-transformed cell line derived from a patient with congenital BLS whose beta cells failed to express $H L A$ class II antigen due to a regulatory defect, was transfected by retrovirus-mediated transfers of cDNAs from $H L A-D R A$ and $H L A-D R B 1 * 0404$ [36-38]. The BLS-1 transfectant used in this particular study was BLS-1.DRB1*0404 kindly provided by Dr G.T. Nepom.

Cytotoxicity assay. The T-cell clones used in this study also had peptide-specific cytotoxic $\mathrm{T}$ lymphocyte (CTL) function as previously described [30]. Standard ${ }^{51} \mathrm{Cr}$ release assays were used to measure their CTL responses [33-35]. For use as CTL targets, BLS-1.DRB1*0404 cells $\left(1 \times 10^{6}\right)$ were sensitised by incubating at $37^{\circ} \mathrm{C}$ for $1 \mathrm{~h}$ with peptide at a final concentration of $10 \mu \mathrm{mol} / 1$ in complete RPMI medium. After sensitisation, $1 \times 10^{6}$ cells were washed once with complete medium and in- 
ternally labelled for $1 \mathrm{~h}$ at $37^{\circ} \mathrm{C}$ with $3700 \mathrm{kBq}$ of $\mathrm{Na}_{2}{ }^{51} \mathrm{CrO}_{4}$ (Amersham, Oakville, Ont., Canada). Radiolabelled target cells were washed four times with medium, then incubated for $4 \mathrm{~h}$ at $37^{\circ} \mathrm{C}$ with T-cells at different effector:target (E:T) ratios in round-bottomed 96-well plates (Nunc). All assays were carried out in triplicate. Per cent specific cytotoxicity was calculated by the formula 100 [(ER-SR)/(MR-SR)], where ER (experimental ${ }^{51} \mathrm{Cr}$ release $)=$ mean $\mathrm{cpm}$ released into the supernatant in the presence of T-cells, using $5 \times 10^{3}$ target cells per well; SR (spontaneous ${ }^{51} \mathrm{Cr}$ release) $=$ mean $\mathrm{cpm}$ in the absence of T-cells determined in four replicate samples and MR (maximum ${ }^{51} \mathrm{Cr}$ release $)=$ mean $\mathrm{cpm}$ in supernatant of target cells incubated with $0.5 \%$ Nonidet-P40 (NP-40) detergent (Sigma, St. Louis, Mo., USA) determined in four replicates. Standard ${ }^{51} \mathrm{Cr}$ release was always greater than $25 \%$ of maximum ${ }^{51} \mathrm{Cr}$ release.

\section{Results}

Beta-cell antigens recognised by immune response cells from patients with Type I diabetes. To properly evaluate the cross-reactivity between viral and betacell proteins which could affect the pathogenesis of Type I diabetes, it is essential to identify cross-reactive determinants not only at the clonal T-cell level but also to examine the response frequencies to them in the general T-cell cohort (i.e. at PMBC bulk culture level). Because the pancreas is not accessible for immunologic study in humans, effector mechanisms must be investigated through cells obtained from peripheral blood. A selected panel of 11 betacell peptides recognised by patients with Type I diabetes [17, 18, 39-41] (Table 1) was, therefore, prepared for this study to examine their co-recognition by PBMC and cross-reaction by clonal T-cells with viral antigens. The peptides, such as beta-cell peptides B2, B3, and B8-B11 were selected because they contain known peptide binding motifs of $H L A$ DR and DQ molecules known to have strong associations with Type I diabetes. These beta peptides share motifs for DR3 molecules (DRB1*0301) and DR4 molecules (DRB1*0401,*0404,*0405) which consist of a hydrophobic residue at position 1 and a negatively charged residue (D or E) at position 4 as previously described [42]. Peptide epitopes B1, B4B7 were previously identified in other studies [39-41]. Some of the GAD peptides used in this study have not been established as naturally processed epitopes.

T-cell responses of 60 patients with Type I diabetes to the 11 beta-cell peptides were examined in proliferation assays (Table 1 and Fig.1). Peptide B2, GAD65(252-266) was recognised by most (77\%) patients recent onset with Type I diabetes (Mean SI: 2.6) and $55 \%$ of patients with late onset diabetes (SI: 2.5), while peptide B10, GAD67(212-226) was recognised by most $(61 \%)$ patients with late onset diabetes (SI: 7.8 ) and $50 \%$ of patients with recent onset diabetes (SI: 3.7). Peptide B6, GAD65(505-519) elic- ited the cellular responses (SI: 3.3 ) of $54 \%$ of patients with recent onset diabetes and $48 \%$ of patients with late onset diabetes (SI: 2.7). Peptide B4, GAD65(274-286) were recognised by $39 \%$ of patients with recent onset diabetes (SI: 2.1) and also $32 \%$ of patients with late onset diabetes (SI: 4.5) (Table 1 and Fig.1). Peptide B2, GAD65(252-266) was recognised by patients with recent onset diabetes at the highest frequency, significantly different $(p<0.002)$ from all other beta peptides except B6, GAD65(505-519) $(p>0.136)$. Peptide B10, GAD67(212-226) elicited the highest stimulation indexes in both groups of patients among the beta peptides (Fig. 1). The responses elicited by B10, GAD67(212-226) were higher than those with other beta peptides $(p<0.001)$ in patients with late onset diabetes (Fig. 1). There were, however, no statistically significant differences in cellular responses (both prevalence and amplitude) to these beta peptides between patients with recent and late diabetes onset, although different trends in response frequency were observed.

Peripheral blood mononuclear cells from two of three $(67 \%)$ patients with CRS-associated Type I diabetes proliferated in response to $\mathrm{B} 2$, GAD65(252-266) and B4, GAD65(274-286) and all three $(100 \%)$ patients responded to B10, GAD67(212-226). Similarly, the PBMC from five of eight CRS patients without Type I diabetes also responded to B2, GAD65(252-266). In contrast to the PBMC from patients with CRS-associated Type I diabetes, however, only one of these patients' PBMC $(12.5 \%)$ responded to B10, GAD67(212-226) and B4, GAD65(274-286).

Cellular immune responses of patients with Type I diabetes to $R V$ and $C X V$ antigens. To examine the crossrecognition of RV antigens and beta-cell antigens by T-cells from different patient cohorts, a panel of 15 peptides (V1-V15) of RV structural protein E1, E2, and $\mathrm{C}$ were selected for this study (Table 2). Peptides V1, V4, V5, V8, V11, V13, V14, V15 are antigenic peptides containing epitopes identified by T-cells from RV seropositive healthy donors or RV vaccinees or both in our previous studies [32, 33, 43, 44]. RV peptides V2, V3, V6, V7, V9, V10, V12 were shown earlier to be recognised by peripheral blood T-cells of CRS patients [31] and included five (V3, V6, V7, V9, V12) which stimulated cellular responses of a CRS patient who also had Type I diabetes. Positive cellular responses to whole RV virus were shown in $77 \%$ of patients with recent onset diabetes and $84 \%$ of patients with late onset Type I diabetes and all 3 patients with CRS-associated Type I diabetes. Two RV peptides, V3, RVE1(157-176) and V15, RVC(255-280) could be recognised by the majority of patients. Peptide V3, RVE1(157-176) resulted in higher stimulation indexes of cellular response 


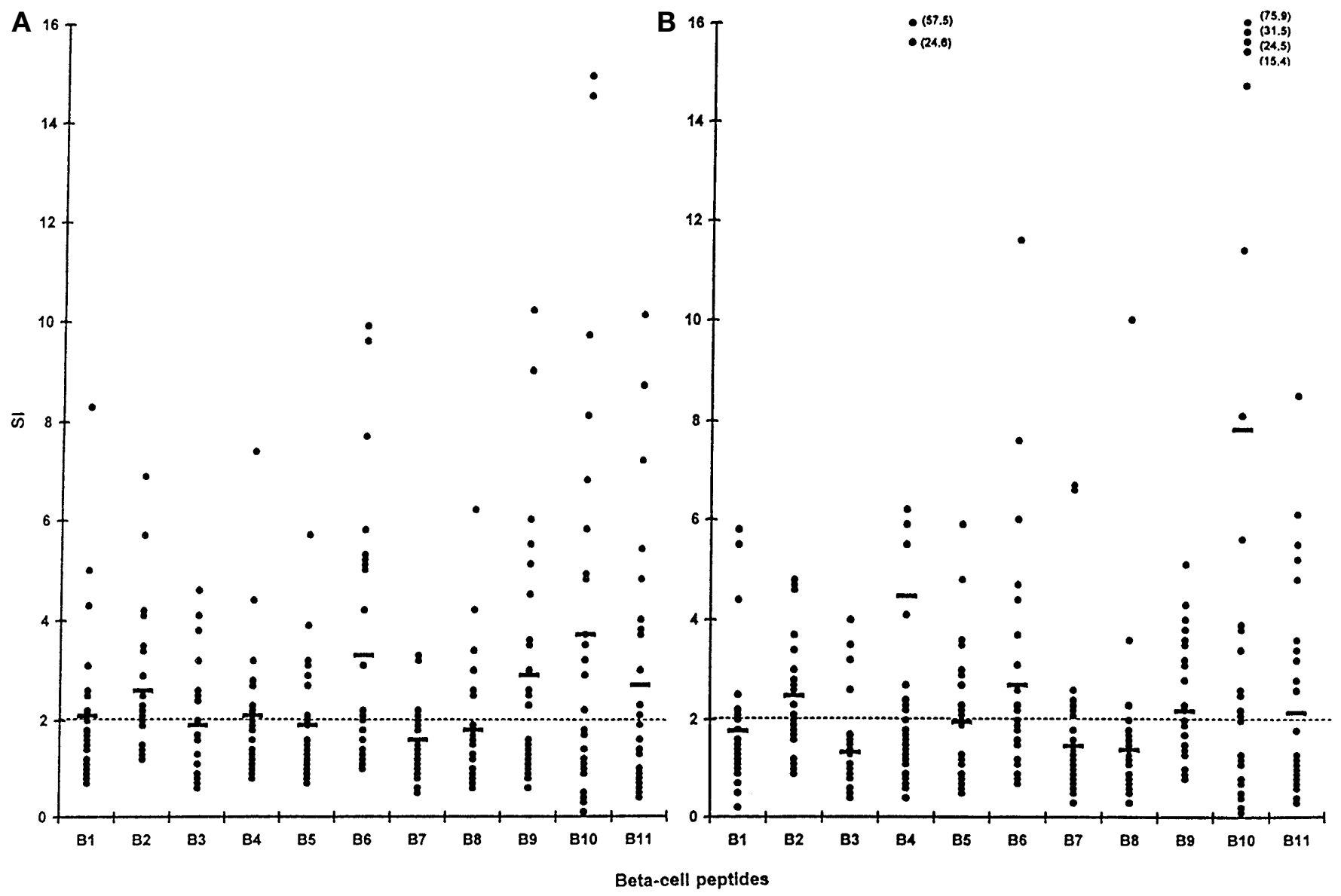

Fig. 1A, B. PBMC responses of patients with recent onset diabetes $(n=26 ; \mathbf{A})$ and patients with late onset diabetes $(n=31$; B) to beta-cell peptides (B1-B11). Each individual response represents the mean of triplicate wells from an individual patient. Solid horizontal bars represent mean responses of bulk cell cultures of patients in the group to the indicated peptide. The horizontal dashed line represents stimulation index (SI) of 2.0, a threshold for positive reactivity

among the viral peptides in patients with recent onset diabetes (SI: 8.2, $p<0.0001)$ as well as patients with late onset diabetes (SI: 12.1, $p<0.0001$ ) (Fig. 2). This RV peptide also induced the highest frequency $(77 \%)$ of positive cellular responses in patients with recent onset diabetes, higher $(p<0.001)$ than all others, except for V12, RVE2(184-198) $(p<0.077)$ and V15, RVC(255-280) $(p<1.0)$. Peptide V3, RVE1(157-176) also induces responses at the highest rate $(74 \%)$ in patients with late onset diabetes, significantly higher $(p<0.001)$ than all others, except for V13, RVE2(244-266) $(p<0.095)$ and V15, RVC $(255-280)(p<0.871)$ (Table 2). Peptide V12, RVE2(184-198) stimulated cellular responses in $46 \%$ of patients with recent onset diabetes (SI: 2.6) and $29 \%$ of patients with late onset diabetes (SI: 1.9). Peptide V9, RVE2(87-107) elicited responses in $39 \%$ of patients with recent onset diabetes (SI:
1.8) and $20 \%$ of patients with late onset diabetes (SI: 1.4) (Table 2 and Fig.2). Peptide V15, RVC(255-280) induced cellular responses in $72 \%$ of patients with recent onset diabetes (SI: 4.9) and $75 \%$ of patients with late onset diabetes (SI: 7.1) (Table 2 and Fig. 2). All three patients with CRS-associated Type I diabetes showed positive responses to peptides V3, RVE1(157-176), V13, RVE2(244-266) and V15, RVC(255-280), while only, respectively 2 of 8,1 of 8 , and 2 of 8 CRS patients without Type I diabetes responded to these peptides. These results suggested that there is a difference between these two groups of patients in response to the three RV peptides.

Two CXV peptides, V16, CXV B4 P2-C(34-48) and V17, CXV B4 P2-C(38-53) were also used in the test panel. V16 elicited positive cellular responses from $39 \%$ of patients with recent onset Type I diabetes (SI: 2.3 ) and $26 \%$ of patients with late onset diabetes (SI: 1.6). Peptide V17 induced responses in only $27 \%$ of patients with recent onset diabetes (SI: 1.7) and $23 \%$ of patients with late onset diabetes (SI:1.6), consistent with the results of a similar study [24]. Only one of three patients with CRS-associated Type I diabetes showed positive responses to these peptides and one of eight patients with CRS without Type I diabetes positively responded to them (Table 2 and Fig. 2). 

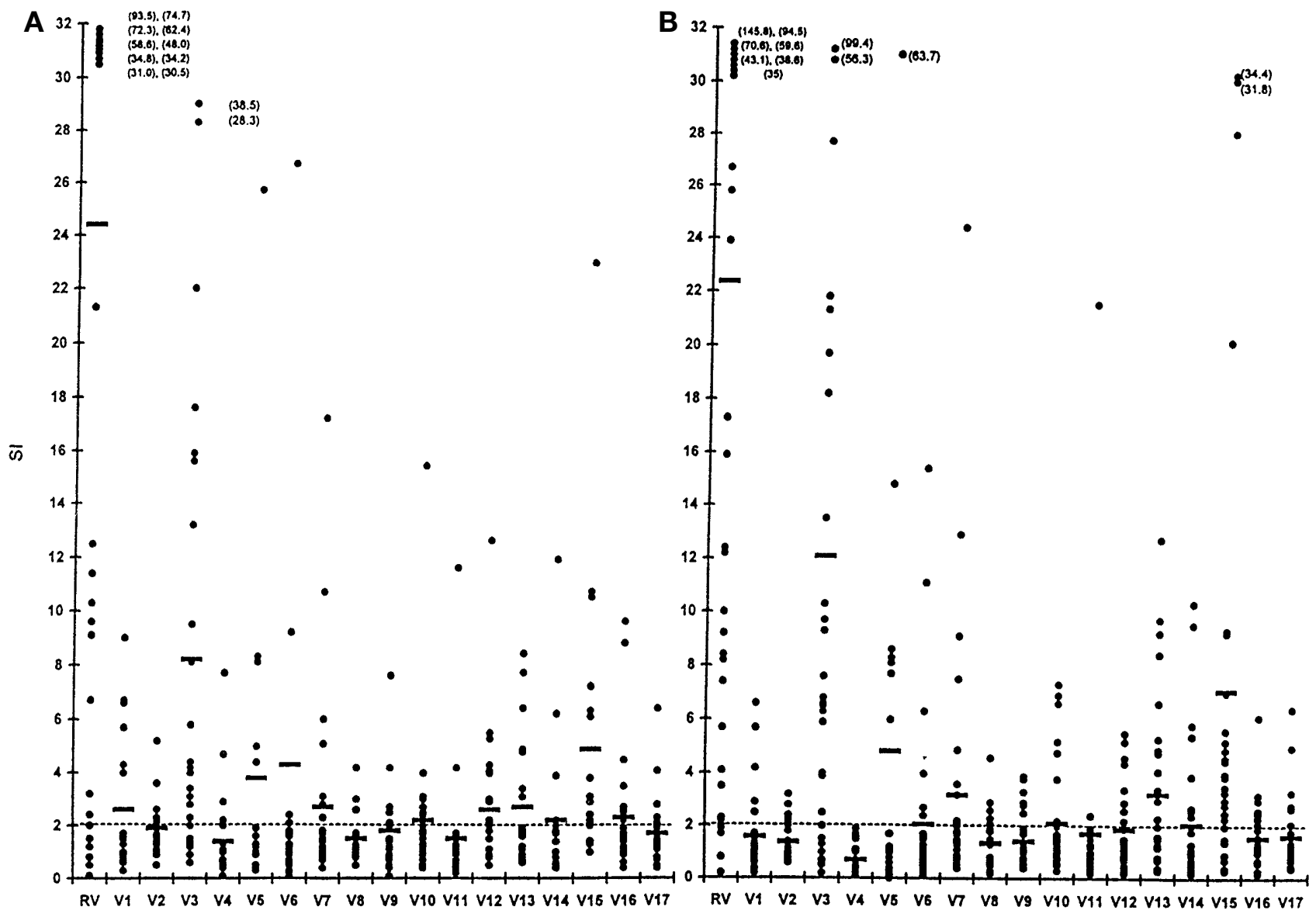

RV peptides

Fig. 2 A, B. PBMC responses of patients with recent onset diabetes $(n=26 ; \mathbf{A})$ and patients with late onset diabets $(n=31$; B) to viral antigens (whole RV virus, RV; RV peptides, V1V15; and CXV peptides, V16 and V17). Each individual response represents the mean of triplicate wells from an individual patient. Solid horizontal bars represent mean responses of bulk cell cultures of patients in the group to the indicated peptide. The horizontal dashed line represents stimulation index (SI) of 2.0, a threshold for positive reactivity

Cross-reaction of GAD (65 and 67) antigen-specific Tcell clones derived from CRS-associated Type I diabetic patients with rubella virus determinants. Only the detection of beta-cell epitope-reactive T-cell clones that recognise the viral counterpart (or vice versa) can prove that cross-reactivity to beta-cell and viral epitopes really exists at the T cell level. While betacell GAD proteins were found as the important target autoantigens in the pathogenesis of Type I diabetes [16-20], T-cell responses to these proteins and their peptides have been studied extensively in nonobese diabetic (NOD) mice and patients with Type I diabetes $[12,13]$. A recent study indicated that GAD (65 and 67) are the essential autoantigens initiating Type I diabetes by activating GAD-specific T-cells [20]. To characterise human Type I diabetes-associat- ed GAD T-cell epitopes, we induced and isolated several CD4+ T-cell clones specific to GAD65(252-266), GAD65(274-286), or GAD67(212-226) from two patients with CRS-associated Type I diabetes, patients SZ and DB [30]. T-cell clone SZ2.6 was derived from a GAD65(252-266)-specific T-cell line from patient SZ. Peptide GAD65(252-266) was able to elicit the specific CTL responses of clone SZ2.6 in the context of HLA DRB1*0404 and DRB1*0301 [30]. Another T-cell clone DB4.7 was isolated from a GAD65(274-286)-specific T-cell line of patient DB. This clone was cytotoxic to peptide GAD65(274-286)-sensitised target cells expressing HLA DRB1*0401, DRB1*0404, DRB1*0405 and DRB1*0301 [30]. Two GAD67(212-226)-specific Tcell clones SZ10.3 and DB10.2 were also derived from these two patients. Peptide GAD67(212-226) was capable of inducing CTL responses of the clones SZ10.3 and DB10.2 in the context of DRB1*0404 and DRB1*0301. Clone SZ10.3 could also respond to this peptide in the context of DRB1*0405, DRB4*0101 and DQ8 (D. Ou, unpublished data). These data indicate that T-cell clones used in this study are quite promiscuous in their recognition. These clones were chosen for this study as T-cell clones with degenerate peptide recognition are more likely to induce an autoimmune responses due to 
Table 4. Specific cytotoxicity of T-cell clones SZ10.3 and DB10.2 to peptide GAD67(212-226) and RV peptides presented by BLS-1.DRB1*0404 cell line

\begin{tabular}{|c|c|c|}
\hline \multirow[t]{2}{*}{ Sensitising peptide } & \multicolumn{2}{|c|}{$\%$ Specific cytotoxicity ${ }^{a}$} \\
\hline & \multicolumn{2}{|c|}{ Effector: Target $=5: 1$} \\
\hline GAD67 (212-226) (B10) & 25.8 & $11.5^{b}$ \\
\hline RVE1 (18-38) & 0 & 0 \\
\hline RVE1 (38-57) & 0 & 4.3 \\
\hline RVE1 (54-74) & 4.8 & 10.2 \\
\hline RVE1 (122-141) & 2.2 & 0 \\
\hline RVE1 (157-176) & $\mathbf{1 7 . 2}$ & 0 \\
\hline RVE1 (174-193) & 0 & 0 \\
\hline RVE1 (190-209) & 0 & 0 \\
\hline RVE1 (256-275) & 3.6 & 0 \\
\hline RVE2 (33-57) & 2.5 & 12.5 \\
\hline RVE2 (87-107) & 5.1 & 0 \\
\hline RVE2 (233-257) & 3.2 & 0 \\
\hline RVC (1-29) & 0 & 5.4 \\
\hline RVC (53-78) & 0.7 & 1.9 \\
\hline RVC (151-179) & 19.6 & 14.0 \\
\hline RVC (177-204) & 0 & 0 \\
\hline RVC (231-257) & 0 & 14.5 \\
\hline NONE & 0 & 0 \\
\hline
\end{tabular}

${ }^{\text {a }}$ BLS-1.DRB1*0404 beta cells were sensitised with peptides at a concentration of $10 \mu \mathrm{mol} / \mathrm{l}$ at $37^{\circ} \mathrm{C}$ for $1 \mathrm{~h}$ and used as target cells in cytotoxicity assays.

${ }^{\mathrm{b}}$ Numbers in boldface indicate \% specific cytotoxicity greater than 10

cross-reactivity between a microbial and a self-peptide [46]. We selected $14 \mathrm{RV}$ peptides containing the binding motifs to HLA class II DR3 (DRB1*0301), DR4 (DRB1*0401, 0402, 0404, 0405) and DQ8 molecules which have been associated with Type I diabetes from the RV peptide panel for examining the cross-reaction of the GAD-specific T-cell clones in cytotoxicity assays (Table 3 ). T-cell clone SZ2.6 specific to B2, GAD65(252-266) also responded to RV peptides RVE1(122-141) and RVE1(157-176) (Table 3). B4, GAD65(274-286)-specific T-cell clone DB4.7 showed cross-reaction with two RV peptides, RVE1(157-176) and RVE2(87-107) (Table 3). The T-cell clones SZ10.3 and DB10.2, specific to B10, GAD67(212-226) also reacted with 2 and 4 RV peptides respectively. T-cell clone SZ10.3 responded to
RVE1(157-176) and RVC(151-179), and T-cell clone DB10.2 cross-reacted to peptides RVE1(54-74), RVE2(33-57), RVC(151-179) and RVC(231-257) (Table 4).

Peptide motifs shared by cross-reactive GAD and rubella antigens. Both the sequences of RV peptides eliciting responses of the T-cell clones and the sequences of the GAD epitope peptides B2, GAD65(252-266), B4, GAD65(274-286) and B10, GAD67(212-226) are shown in Table 5. All crossreactive RV peptides contain similar motifs with a large hydrophobic residue at position 1 and a negatively charged residue at position 4 which are also found in GAD65(252-266), GAD65(274-286) and GAD67(212-226).

Correlation of the responses of PBMC bulk culture to cross-reactive $R V$ and $G A D$ determinants in patients with Type I diabetes. To determine if the cross-reactivities between viral and beta-cell peptides observed with the Type I diabetic patient T-cell clones (described above) also existed in the general peripheral blood lymphocyte cohort of patients with Type I diabetes, we analysed results of the bulk culture cellular responses of patients to the cross-reactive peptides using the Pearson's correlation test. Three cross-reactive RV determinants, V3, RVE1(157-176), V8, RVE2(33-57) and V9, RVE2(87-107) identified by GAD peptide-specific T-cell clones were included in the viral peptide panel used for patient bulk cell culture assays in this study (Tables 2-4). Significant correlations of bulk culture cellular responses to the cross-reactive determinants identified using T-cell clones were found between V3, RVE1(157-176) and B4, GAD65(274-286) $(r=0.503, p<0.009)$ in patients with recent onset diabetes (Fig.3), between V3, RVE1(157-176) and B10, GAD67(212-226) $(r=0.703, p<0.0001)$ in patients with late onset diabetes (Fig. 3), and between V9, RVE2(87-107) and B4, GAD65(274-286) $(r=0.743, p<0.0001)$ in patients with recent onset diabetes (Fig. 3).

Table 5. Motifs shared by cross-reactive GAD protein and RV determinants recognised by GAD peptide-specific T-cell clones

$\begin{array}{ll}\text { Sequences of GAD epitopes recognised by T-cell clones: } \\ \text { GAD65 (252-266) (B2) } & \text { M I A R F K M F P E V K E K G } \\ \text { GAD65 (274-286) (B4) } & \text { I A F T S E H S H F S L K } \\ \text { GAD67 (212-226) (B10) } & \text { N M F T Y E I A P V F V L M E } \\ \text { Sequences of cross-reactive RV epitopes recognised by GAD peptide-specific T-cell clones: } \\ \text { RVE1 (122-141) } & \text { A F G H S D A A C W G F P T D T V M S V } \\ \text { RVE1 (157-176) } & \text { R V K F H T E T T V W Q L S V A G V S C } \\ \text { RVE2 (33-57) } & \text { P F L G H D G H H G G T L R V G Q H H R N A S D V } \\ \text { RVE2 (87-107) } & \text { M D F W C V E H D R P P P A T P T L T T } \\ \text { RVC (151-179) } & \text { E A C V T S W LW S E G E G A V F Y R V D L H F I N L G T } \\ \text { RVE1 (54-74) } & \text { P T D V S C E G L G A W V P T A P C A R I }\end{array}$

${ }^{a}$ Peptide sequences were shown by the one letter amino acid code. Bold amino acids are the motifs shared by these peptides 


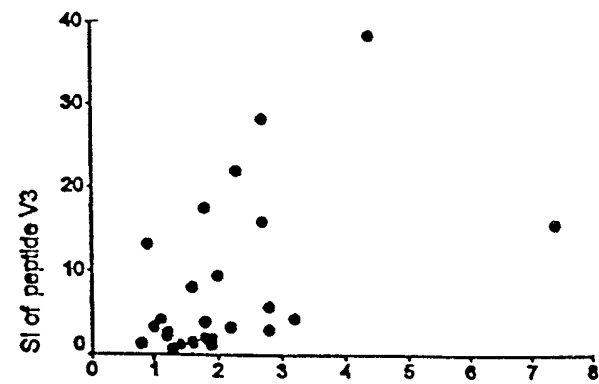

A SI $\propto$ peptide B4

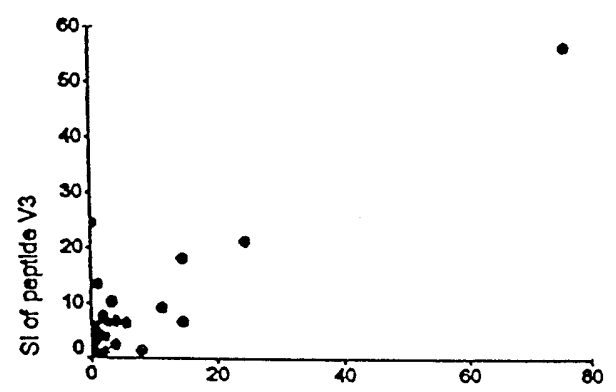

B Sl of peptide $B 10$

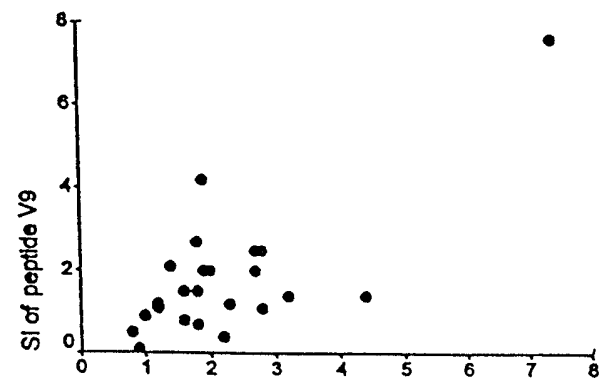

C Sl of peptide $\mathrm{B4}$

Fig. 3 A-C. Correlation between the cellular responses of patients to GAD peptides and to RV peptides. The correlation of the PBMC responses to GAD and RV peptides was examined by the chi-squared test: $\mathbf{A}$ correlation between the responses to peptide B4, GAD65(274-286) and peptide V3, RVE1(157-176) $(r=0.503, p<0.009)$; $\mathbf{B}$ correlation between the responses to peptide B10, GAD67(212-226) and peptide V3, RVE1(157-176) $(r=0.703, p<0.0001)$; and $\mathbf{C}$, correlation between the responses to peptide B4, GAD65(274-286) and peptide V9, RVE2(87-107) $(r=0.743, p<0.0001)$. A and $\mathbf{C}$ recent onset patients $(n=26$ in each). B late onset patients $(n=31)$

\section{Discussion}

Cross-reaction between virus and self-protein antigens based on antigenic molecular mimicry triggered by viral infection has been recently proved to be an important pathogenetic mechanism in a murine model of autoimmune herpes stromal keratitis [47]. Neither the initial target of attack on beta cells for autoreactive killer T-cells nor the nature of the environmental factor implicated in Type I diabetes have how- ever, so far been identified. Promiscuous recognition of multiple major histocompatibility complex (MHC)-peptide epitope complexes is a well known and essential feature of the T-cell receptor (TCR). The recent confirmation of degeneracy in T-cell recognition using peptide combinatorial libraries indicated that a wide range of ligands with different affinities exists for each TCR. A single TCR has the capacity to recognise approximately $10^{6}$ different MHC-associated minimal peptide epitopes [48, 49]. This diversity allows for cross-recognition of pathogen and self-epitopes. To identify the cross-reactive rubella virus and beta-cell protein determinants and also to evaluate the importance of such determinants involved in the pathogenesis of Type I diabetes, we studied the T-cell responses to these determinants at both bulk cell culture and cloned T-cell levels. Autoimmune T-cell responses to peptide determinants of beta-cell proteins have been characterised in nonobese diabetic (NOD) mice and human patients with Type I diabetes [12, 13, 17, 18, 41, 50-57]. Studies in NOD mice showed that T-cell responses to GAD antigens arose in a sequential order and that T-cell responses to epitopes GAD65(78-97), GAD65(202221), GAD65(217-236), GAD65(247-266), GAD65(509-528) or GAD(524-543) might be used as staging markers for Type I diabetes progression $[56,57]$. At least 15 GAD65 T-cell epitopes recognised by humans with Type I diabetes have also been identified [12, 41, 50-52, 55]. In this study we used a panel of beta-cell peptides which represented the identified Type I diabetes-associated antigens to test the peptide-specific T-cell responses of Type I diabetes patients at different disease stages. Among the 11 beta-cell peptides, B2 representing GAD65(252-266) was recognised with the highest frequency of $77 \%$ in patients with recent onset diabetes. Peptide B10, GAD67(212-266) elicited the highest stimulation indexes in patients with both recent and late onset diabetes and with the highest recognition rate of $61 \%$ in patients with late post onset diabetes. This study also showed T-cell responses of patients with Type I diabetes to several GAD67 epitopes. Similar reciprocal GAD65-67 T-cell recognition during the disease progression has been reported in the studies of NOD mice [57]. A study in human Type I diabetes showed that increased T-cell responses to a recombinant GAD67(208-404) containing the sequences of four beta peptides used in the present study, was a marker of preclinical Type I diabetes [17]. As with previous observations in NOD mice, our results suggest that there are two opposing tendencies that characterise the T-cell responses to beta-cell antigens. There appears to be a drive towards relative immunodominance of some peptides but also an apparent diversification and broadening of specificity suggesting epitope spreading with disease progression. Studies in autoimmune mouse mod- 
els show that either initial determinant or spreading determinants could be critical in the pathogenesis of autoimmune diseases [56, 57]. Many instances of organ-specific autoimmunity also show such clusters of target determinants that become involved [58]. The beta-cell epitopes recognised by most patients with Type I diabetes in this study such as B2, GAD65(252-266), B6, GAD65(505-519) and B10, GAD67(212-226) which are included in the identified staging markers of Type I diabetes should therefore be further studied as the candidate triggers or mediators in pathogenesis. The GAD65(274-286) epitope has been identified as one recognised by Tcells from both human and HLA-DRB1*0401 transgenic mice [41]. T-cell clones specific to these betacell antigens have therefore been isolated for characterising the epitopes and examining their cross-reaction with viral antigens [30]. Several GAD65 T-cell epitopes have recently, been identified using T-cell hybridomas derived from NOD mice and human DQ8 transgenic mice [59, 60]. Peptide GAD65(206-220) has been determined as the most dominant T-cell epitope restricted by mouse $\mathrm{I}-\mathrm{Ag}^{7}$ in NOD mice [59]. This epitope is also recognised by PBMC from patients with Type I diabetes and restricted by DQ8 [60]. The core epitope GAD65(208-217) of this peptide is homologous to human GAD67(217-226) with only one conservative substitution ( $\mathrm{m}$ to $\mathrm{l}$ ) at position 216 of GAD65. Notably, this study also showed that the peptide GAD67(212-226) containing GAD67(217-226) is an important epitope recognised by the PBMC from most patients with Type I diabetes. As mentioned above, GAD67(212-226) could be recognised by T-cells in the context of DRB1*0301, 0404, 0405, B4*0101 and DQ8.

Viral infections could induce and sustain autoimmune processes by several overlapping mechanisms including priming of autoreactive T-cells which have escaped thymic tolerance and are able to mount a cross-reactive response to mimetic antigens carried by viruses in the periphery [46, 61]. Although it has been shown in NOD mice that cross-reactivity to GAD65 and CXV protein P2-C is detectable at the T-cell line [23], it has not been proved in humans. So far, one study described co-recognition of the CXV peptides in $\mathrm{P} 2-\mathrm{C}(32-47)$ and its antigenic counterpart of GAD65 peptides in GAD65(247-279) by investigating at the PBMC culture level [24]. A recent study showed, however, that CXV infection did not increase splenocyte responses in NOD mice to GAD65(255-269) and CXV(32-47) [8]. We observed that over $80 \%$ of patients with Type I diabetes showed positive cellular responses to whole rubella virus. Two rubella peptides, V3, RVE1(157-176) and V15, RVC(255-280) elicited cellular responses in over $70 \%$ of patients with Type I diabetes and all CRS patients with Type I diabetes. All four GAD peptide-specific T-cell clones also responded with two or more rubella peptides suggesting that cross-reaction of viral antigen with GAD antigens could play a part in the pathogenesis of Type I diabetes triggered by RV infection. Peptide V3, RVE1(157-176) was first found to induce cellular responses in a patient with CRS-associated Type I diabetes and only $10 \%$ RV seropositive healthy people and vaccinees in our previous study [31] and hence was included in the RV peptide panel for this study. Cross-reactive RV determinants such as V3, RVE1(157-176) were found to induce a higher frequency of cellular response in the cohort of patients with Type I diabetes than two CXV peptides which shared $80 \%$ homology to GAD65 peptides, suggesting that these RV determinants could be more important in the pathogenesis of Type I diabetes than those of CXV.

Comparing the sequences of the GAD epitopes recognised by the T-cell clones and the cross-reactive rubella peptides shows that all these peptides contain motifs with a large hydrophobic residue at position 1 and a negatively charged residue at position 4 . These motifs are also the minimal peptide binding motifs of DR3 and DR4 (DRB1*0401, *0404, and *0405) molecules which have been associated with Type I diabetes. Microbial peptides with limited sequence homology are effective activators of autoreactive T-cells $[62,63]$. It has recently been shown that monoclonal and polyclonal GAD65(248-257) or GAD65(88-99)-specific T-cells from patients with Type I diabetes could be stimulated by viral (human herpes virus) and bacterial peptides with little apparent sequence homology with autoantigenic epitopes [64]. The study did not, however, examine the co-recognition of the cross-reactive viral and bacterial antigens at bulk cell culture level in the patient cohort and thus could not evaluate the importance of the cross-reactive peptides in the pathogenesis of Type I diabetes. Peptide V2, RVE1(157-171) with 15 of 21 overlapping residues with its analog, V3, RVE1(157-176) elicited lower stimulation indexes and response frequencies of patients than the latter in the present study. A similar response to B3, GAD65(256-279), compared with that of B2, GAD65(252-266) was observed in this study. These results underscore the vital part played by the amino acid residues that flank the core antigenic determinant on the outcome of the response [65]. It has been reported that different TCRs can recognise the same peptide/MHC complex [66, 67]. Similarly, different GAD-specific T-cell clones could respond to the same peptide V3, RVE1(157-176) in the present study.

The cross-reaction between GAD (65 and 67) epitopes and rubella virus determinants at the cloned Tcell level and co-recognition at patient bulk cell culture level imply that rubella infection could be one of the triggering factors, boosting GAD epitoperesponding T-cells, driving or increasing the natural 
spreading of T-cell immunity to the GAD determinants. Pearson's correlation test results showed significant correlations between the responses to V3, RVE1(157-176) and B4, GAD67(274-286) in patients with recent onset diabetes and the responses to another cross-reactive determinant B10, GAD67(212-226) in patients with late onset diabetes. Significant correlation was also found between V9, RVE2(87-107) and B4, GAD65(274-286) responses, suggesting that the cross-reaction observed in T-cell clones was also represented in the general T-cell cohort of patients with Type I diabetes. The bulk cell culture responses to B2, GAD65(252-266) did not, however, show correlation to the responses to V3, RVE1(157-176), although the T-cell clone specific to B2 also cross-reacted with V3. Similarly, no correlation was found in bulk cell culture responses between B10, GAD67(212-226) and V8, RVE2(33-57) although the two determinants are cross-reactive at T-cell clone level. In contrast to the responses of cloned T-cells, bulk culture cell responses of patients with different HLA phenotypes included the responses of heterogeneous T-cells. Many other factors other than cross-reaction such as antigenic specificity, phenotypes (CD4 or CD8), HLA restrictions, responder cell frequencies and affinity could influence the results of T-cell function assays. Also, B2, GAD65(252-266) is an immunodominant epitope promiscuously recognised by most healthy people with different $H L A$ phenotypes ([68], and D. Ou, unpublished data). Moreover, the responses to peptide B2, GAD65(252-266) could be boosted not only by V3, RVE1(157-176) but also by other cross-reactive viral antigens such as the CXV B4 P2-C peptides sharing the same sequence (PEVKEK) and seven other similar residues in adjacent regions with B2 peptide $[15,23]$. Similarly, the responses to B10, GAD67(212-266) could be driven by not only crossreactive determinant V8, RVE2(33-57) but also V3, RVE1(157-176). In these cases, it is not surprising that the bulk cell culture responses of a patient cohort to a pair of cross-reactive viral and GAD determinants show no correlation.

Similar to the observations in NOD mice $[56,57]$, the present study showed that the recognition frequency in patients with Type I diabetes for some GAD epitopes, such as B2, GAD65(252-266) decreased with disease progression, whereas the responding rate to other GAD epitopes, such as B4, GAD67(212-226) seemed to increase. No significant differences were found however, in responses to beta and $\mathrm{V}$ peptides between recent onset and late onset patient groups. It is possible that the interval from recent onset to late onset in this study was too short to detect differences or that the major changes of responses to GAD epitopes could occur much earlier in the prediabetic stage as described in NOD mice studies $[56,57]$. To fully understand the cross-reac- tion of viral and autoantigenic epitopes in triggering human Type I diabetes and in disease progression it will be necessary to study these responses prospectively from the prediabetic state to advanced Type I diabetes. This study established the cross-reactivity between rubella virus and GAD antigens.

Type I diabetes that is CRS-associated has been used as a model to study the viral influences in the pathogenesis of the disease $[7,30]$. The present study suggests that the positive frequencies responding to cross-reactive determinents beta-cell epitopes B4, GAD65(274-286) and B10, GAD67(212-226), and RV peptides V3, RVE1(157-176) of PBMC from patients of CRS-associated Type I diabetes seem to be higher than those of PBMC from patients of CRS without Type I diabetes. Whether or not these differences are statistically significant and associated with Type I diabetes remains to be analysed statistically by comparing matched patients from the two groups. We are recruiting more CRS patients to increase the study sample size, helped by a national network programme. Several live attenuated rubella vaccines have been introduced since 1969 and immunisation of infants is now a standard public health measure. Most patients with Type I diabetes in this study should have been infected or immunised by the RV as over $80 \%$ of patients showed cellular responses to whole RV virus and almost all of them are under 20 years old. Rubella virus (255-280) is an immunodominant T-cell epitope identified in previous studies which was recognised by most seropositive healthy donors and RV vaccinees with different HLA phenotypes [31, 32]. This study showed that $72-75 \%$ of patients with Type I diabetes recognise this peptide. Positive response to this peptide also indicates that the host is likely immune to RV. Moreover, 74-77\% of PBMC from these patients responded to a GAD antigen cross-reactive RV determinant RVE1(157176). We shall, therefore, be interested to know whether RV infection or current RV vaccination or both influences the incidence and disease progression of conventional Type I diabetes patients. It is unlikely, however, that a single microbial peptide is responsible for the activation of autoreactive T-cells in human Type I diabetes because microbial peptides with limited sequence homology are effective activators of autoreactive T-cells [46]. As some autoreactive T-cell clones are activated by peptides from different pathogens, a stepwise expansion of autoreactive T-cells by subsequent infection is possible [46, 61].

Acknowledgements. The authors thank Dr. G. T. Nepom of the Virginia Mason Research Center, Seattle, Wash. USA. for providing the BLS-1 transfectant for this study. This work was supported by CKNW Orphans Fund Endowment in Paediatric Immunology, F \& G Heighway Foundation and Canadian Diabetes Association. A.J. Tingle is a recipient of the Career Investigatorship Award of the British Columbia's Children's Hospital Foundation. 


\section{References}

1. Yoon JW, Jun HS, Santamaria P (1998) Cellular and molecular mechanisms for the initiation and progression of $\beta$ cell destruction resulting from the collaboration between macrophages and T cells. Autoimmunity 27: 109122

2. Bach JF (1994) Insulin-dependent diabetes mellitus as an autoimmune disease. Endocrine Rev 15: 516-541

3. See DM, Tilles JG (1996) Pathogenesis of viral-induced diabetes. Current Opinion in Infections Diseases 9: 161-164

4. Yoon JW (1995) A new look at viruses in Type I diabetes. Diabetes Metab Rev 11: 83-107

5. Ginsberg-Fellner F, Fedum B, Cooper Z (1986) Interrelationship of congenital rubella and Type I insulin-dependent diabetes. In: Jaworski MA, Molner GD, Rajotte RV, Singh B (eds) The immunology of diabetes mellitus. Elsevier Science, Amsterdam, pp 279-286

6. Menser MA., Forrest JM, Honeyman MC, Burgess JA (1974) Diabetes, HLA-antigens, and congenital rubella. Lancet ii: $1508-1509$

7. Ginsberg-Fellner F, Witt ME, Yagihashi S et al. (1984) Congenital rubella syndrome as a model for Type I (insulin-dependent) diabetes mellitus:increased prevalence of islet cell surface antibodies. Diabetologia 27: 87-89

8. Horwitz MS, Bradley LM, Harbertson J, Krahl T, Lee J, Sarvetnick N (1998) Diabetes induce by Coxsackie virus:Initiation by bystander damage and not molecular mimicry. Nat Med 4: 781-785

9. von Herrath MG, Evans CF, Horwitz MS, Oldstone MBA (1996) Using transgenic mouse models to dissect the pathogenesis of virus-induced autoimmune disorders of the islets of langerhans and the central nervous system. Immunol Rev 152: 111-143

10. Nepom GT (1995) Glutamic acid decarboxylase and other autoantigens in IDDM. Cur Opin Immunol 7: 825-830

11. Roep BO (1996) T-cell responses to autoantigens in IDDM:The search for the holy grail. Diabetes 45: 1147-1156

12. Bach JM, Otto H, Nepom GT et al. (1997) High affinity presentation of an autoantigenic peptide in Type I diabetes by an HLA class II protein encoded in a haplotype protecting from disease. J Autoimmunity 10: 375-386

13. Bach JF, Koutouzov S, van Endert PM (1998) Are there unique autoantigens triggering autoimmune disease? Immunol Rev 164: 139-155

14. Bu DF, Erlander MG, Hitz BC et al. (1992) Two human glutamate decarboxylases, 65-KDa GAD and 67-KDa GAD are each encoded by single gene. Proc Natl Acad Sci USA 89: 2115-2119

15. Kaufman DL, Erlander, MG, Clare-Salzler M, Atkinson MA, Maclaren NK, Jobin AJ (1992) Autoimmunity to two forms of Glutamate decarboxylase in insulin-dependent diabetes mellitus. J Clin Invest 89: 283-292

16. Bonifacio E, Genovese S, Braghi S et al. (1995) Islet autoantibody markers in IDDM:risk assessment strategies yielding high sensitivity. Diabetologia 38: 816-822

17. Honeyman MC, Cram DS, Harrison LC (1993) Glutamic acid decarboxylase 67-reactive T cells:A marker of insulindependent diabetes. J Exp Med 177: 535-540

18. Lohmann T, Leslie RDG, Hawa M, Geysen M, Rodda S, Londei M (1994) Immunodominant epitopes of glutamic acid decarboxylase 65 and 67 in insulin-dependent diabetes mellitus. Lancet 343: 1607-1608

19. Zekzer D, Wong FS, Ayalon O et al. (1998) GAD-reactive CD4 + Th1 cells induce diabetes in NOD/SCID mice. J Clin Invest 101: 68-73
20. Yoon JW, Yoon CS, Lim HW et al. (1999) Control of autoimmune diabetes in NOD mice by GAD expression or suppression in $\beta$ cells. Science 284: 1183-1187

21. Baekkeskov S, Nielson JH, Marner B, Bilde T, Ludvigsson J, Lermmark A (1982) Autoantibodies in newly diagnosed diabetic children immunoprecipitate human pancreatic islet cell proteins. Nature 298: 167-169

22. Hou J, Said C, Franchi D, Dockstander P, Chatterjee NK (1994) Antibodies to glutamic acid decarboxylase and P2$\mathrm{C}$ peptides in sera from Coxsackie virus B4-induced mice and IDDM patients. Diabetes 43: 1260-1268

23. Tian J, Lehmann PV, Kaufman DL (1994) T cell cross-reactivity between Coxsackievirus and glutamate decarboxylase is associated with a murine diabetes susceptibility allele. J Exp Med 180: 1979-1984

24. Atkinson MA, Bowman MA, Campbell L, Darrow BL, Kaufman DL, Maclaren NK (1994) Cellular immunity to a determinant common to glutamate decarboxylase and Coxsackie virus in insulin-dependent diabetes. J Clin Invest 94: 2125-2129

25. Karounos DG, Wolinsky JS, Thomas JW (1993) Monoclonal antibody to rubella virus capsid protein recognises a $\beta$-cell antigen. $\mathrm{J}$ Immunol 150: 3080-3085

26. Jones DB, Crosby L (1996) Proliferative lymphocyte responses to virus antigens homologous to GAD65 in IDDM. Diabetologia 39: 1318-1324

27. Monif GRG, Avery GB, Korones SB, Sever JL (1965) Postmortem isolation of rubella virus from three children with rubella-syndrome defects. Lancet i:723-724

28. Numazaki K, Goldman HY, Wong I, Wainberg MA (1989) Infection of cultured human fetal pancreatic islet cells by rubella virus. Am J Clin Pathol 91: 446-451

29. Rubinsten P, Walker ME, Fedun B, Witt ME, Cooper LZ, Ginsberg-Fellner F (1982) The HLA system in congenital rubella patients with and without diabetes. Diabetes 31: 1088-1091

30. Ou D, Jonsen LA, Metzger DL, Tingle AJ (1999) CD4 ${ }^{+}$ and $\mathrm{CD}^{+} \mathrm{T}$ cell clones from congenital rubella syndrome patients with IDDM recognised overlapping GAD65 protein epitopes:Implications for HLA class I and II allelic linkage to disease susceptibility. Hum Immunol 60: 652-664

31. Ou D, Chong P, Tingle AJ, Gillam S (1993) Mapping T-cell epitopes of rubella virus structural proteins E1, E2, and C recognised by T-cell lines and clones derived from infected and immunized populations. J Med Virol 40: 175-183

32. Ou D, Chong P, Tripet B, Gillam S (1992) Analysis of Tand B-cell epitopes of capsid protein of rubella virus by using synthetic peptides. J Virol 66: 1674-1681

33. Ou D, Mitchell LA, Ho M et al. (1994) Analysis of overlapping T- and B-cell antigenic sites on rubella virus E1 envelop protein:influence of HLA-DR polymorphism of T-cell clonal recognition. Hum Immunol 39: 177-187

34. Ou D, Mitchell LA, Domeier ME et al. (1996) Characterization of HLA restrictive elements of rubella virus-specific cytotoxic T-cell clone:Influence of HLA-DR $4 \beta$ chain residue 74 polymorphism on $\mathrm{Ag}$ peptide-T cell interaction. Int Immunol 8: 1577-1586

35. Ou D, Mitchell LA, Décarie D, Gillam S, Tingle AJ (1997) Characterization of overlapping $\mathrm{CD}^{+}$and $\mathrm{CD} 4^{+} \mathrm{T}$-cell epitope on rubella capsid protein. Virology 235: 286-291

36. Hiraiwa A, Yamanaka K, Kwok WW et al. (1990) Structural requirements for recognition of the HLA-Dw14 class II epitope: a key HLA determinant associated with rheumatoid arthritis. Proc Natl Acad Sci USA 87: 8051-8055

37. Kovats S, Drover S, Marshall WH et al. (1994) Coordinate defects in human histocompatibility leukocyte antigen class 
II expression and antigen presentation in Bare lymphocyte Syndrome. J Exp Med 179: 2017-2022

38. Ou D, Mitchell LA, Décarie D, Tingle AJ, Nepom GT (1998) Promiscuous T-cell recognition of a rubella capsid protein epitope restricted by DRB1*0403 and DRB1*0901 molecules sharing an HLA DR supertype. Hum Immunol 59: 149-157

39. Lohmann T, Leslie RDG, Londei M (1996) T cell clones to epitopes of glutamic acid decarboxylase 65 raised from normal subjects and patients with insulin-dependent diabetes. J Autoimmunity 9: 385-389

40. Neophytou PI, Roep BO, Arden SD et al. (1996) T-cell epitope analysis using subtracted expression libraries (TEASEL):Application to a $38-\mathrm{KDa}$ autoantigen recognised by $\mathrm{T}$ cells from an insulin-dependent diabetic patient. Proc Natl Acad Sci USA 93: 2014-2018

41. Wicker LS, Chen SL, Nepom GT et al. (1996) Naturally processed $\mathrm{T}$ cell epitopes from human glutamic acid decarboxylase identified using mice transgenic for the diabetesassociated human MHC class II allele, DRB1*0401. J Clin Invest 98: 2597-2603

42. Rammensee HG, Feiede T, Stevanović S (1995) MHC ligands and peptide motifs: first listing. Immunogenetics 41: 178-228

43. Ou D, Chong P, McVeish P, Jefferies WA, Gillam S (1992) Characterization of the specific and genetic restriction of human $\mathrm{CD}^{+}$cytotoxic T cell clones reactive to capsid antigen of rubella virus. Virology 191: 680-686

44. Ou D, Chong P, Choi Y et al. (1992) Identification of epitopes on E2 protein of rubella virus, as recognised by human CD4 $4^{+}$cytotoxic T cell clones. J Virol 66: 6788-6793

45. Syren K, Lindsay L, Stoehrer B et al. (1996) Immune reactivity of diabetes-associated human monoclonal autoantibodies in glutamate detects two domain boundaries in glutamate decarboxylase. J Immunol 157: 5208-5214

46. Hausmann S, Wucherpfennig W (1997) Activation of autoreactive $\mathrm{T}$ cells by peptides from human pathogens. Curr Opin Immunol 9: 831-838

47. Zhao ZS, Granucci F, Yeh L, Schaffer PA, Cantor H (1998) Molecular mimicry by herpes simplex virus-Type I:autoimmune disease after viral infection. Science 279: 1344-1347

48. Mason D (1998) A very high level of crossreactivity is an essential feature of the T-cell receptor. Immunol Today 19: 396-404

49. Hemmer B, Vergelli M, Pinilla C, Houghten R, Martin R (1998) Probing degeneracy in T-cell recognition using peptide combinatorial libraries. Immunol Today 19: 163-168

50. Endl J, Otto H, Jung G et al. (1997) Identification of naturally processed $\mathrm{T}$ cell epitopes from glutamic acid decarboxylase presented in the context of HLA-DR alleles by $\mathrm{T}$ lymphocytes of recent onset IDDM patients. J Clin Invest 99: 2405-2415

51. Tabata H, Kanai T, Yoshizumi H et al. (1998) Characterization of self-glutamic acid decarboxylase 65-reactive CD4 + T-cell clones established from Japanese patients with insulin-dependent diabetes mellitus. Hum Immunol 59: 549-560

52. Boyton RJ, Lohmann T, Londei M et al. (1998) Glutamic acid decarboxylase $\mathrm{T}$ lymphocyte responses associated with susceptibility or resistance to Type I diabetes:analysis in disease discordant human twins, non-obese diabetic mice and HLA-DQ transgenic mice. Int Immunol 10: $1765-1776$
53. Kaufman DL, Clare-Salzler M, Tian J et al. (1993) Spontaneous loss of T-cell tolerance to glutamic acid decarboxylase in murine insulin-dependent diabetes. Nature 366: 69-72

54. Zeche MA, Elliott JF, Atkinson MA, Singh B (1998) Characterization of novel T-cell epitopes on $65 \mathrm{kDa}$ and $67 \mathrm{kDa}$ glutamic acid decarboxylase relevant in autoimmune responses in NOD mice. J Autoimmunity 11: 83-95

55. Panina-Bordignon P, Lang R, van Endert PM et al. (1995) Cytotoxic T cells specific for glutamic acid decarboxylase in autoimmune diabetes. J Exp Med 181: 1923-1927

56. Tian J, Olcott AP, Hanssen LR, Zekzer D, Middleton B, Kaufman DL (1998) Infectious Th1 and Th2 autoimmunity in diabetes-prone mice. Immunol Rev 164: 119-127

57. Zechel MA, Krawetz MD, Singh B (1998) Epitope dominance:evidence for reciprocal determinant spreading to glutamic acid decarboxylase in non-obese diabetic mice. Immunol Rev 164: 111-118

58. Sercarz EE (1998) Immune focusing vs diversification and their connection to immune regulation. Immunol Rev 164: $5-10$

59. Chao CC, Sytwu HK, Chen EL, Toma J, McDevitt HO (1999) The role of MHC class II molecules in susceptibility to Type I diabetes:Identification of peptide epitopes and characterization of the $\mathrm{T}$ cell repertoire. Proc Natl Acad Sci USA 96: 9299-9304

60. Herman, AE, Tisch RM, Patel SD et al. (1999) Determination of glutamic acid decarboxylase 65 peptides presented by the Type I diabetes-associated HLA-DQ8 class II molecule identifies an immunogenic peptide motif. J Immunol 163: 6275-6282

61. von Herrath MG (1998) Selective immunotherapy of IDDM:A discussion based on new findings from the RIPLCMV model for autoimmune diabetes. Transplant Proc 30: 4115-4121

62. Wucherpfennig KW, Strominger JL (1995) Molecular mimicry in T cell-mediated autoimmunity:viral peptides activate human $\mathrm{T}$ cells clones specific for myelin basic protein. Cell 80: 695-705

63. Rosa FD, Barnaba V (1998) Persisting viruses and chronic inflammation:understanding their relation to autoimmunity. Immunol Rev 164: 17-27

64. Bach JM, Otto H, Jung G et al. (1998) Identification of mimicry peptides base on sequential motifs of epitopes derived from $65-\mathrm{kDa}$ glutamic acid decarboxylase. Eur Immunol 28: 1902-1910

65. Moudgil KD, Sercarz EE, Grewal LS (1998) Modulation of the immunogenicity of antigenic determinants by their flanking residues. Immunol Today 19: 217-220

66. Ding YH, Smith KL, Garboczi DN, Utz U, Biddison WE, Wiley DC (1998) Two human T cell receptors bind in a similar diagonal mode to the HLA-A2/Tax peptide complex using different TCR amino acids. Immunity 8: 403-411

67. Janeway CA Jr (1998) A tale of two T cells. Immunity 8: 391-394

68. Schloot NC, Roep BO, Wegmann DR, Yu L, Wang T, Eisenbarth GS (1997) T-cell reactivity of GAD65 peptide sequences shared with Coxsackievirus protein in recent onset IDDM, post onset IDDM patients and control subjects. Diabetologia 40: 332-338 